\title{
A House Burning at Redwine (41SM193)
}

\section{Mark Walters}

Heritage Research Center, Stephen F. Austin State University

Follow this and additional works at: https://scholarworks.sfasu.edu/ita

Part of the American Material Culture Commons, Archaeological Anthropology Commons, Environmental Studies Commons, Other American Studies Commons, Other Arts and Humanities Commons, Other History of Art, Architecture, and Archaeology Commons, and the United States History Commons

Tell us how this article helped you.

This Article is brought to you for free and open access by the Center for Regional Heritage Research at SFA ScholarWorks. It has been accepted for inclusion in Index of Texas Archaeology: Open Access Gray Literature from the Lone Star State by an authorized editor of SFA ScholarWorks. For more information, please contact cdsscholarworks@sfasu.edu. 
A House Burning at Redwine (41SM193)

Creative Commons License

(c) $)(1)$ (9)

This work is licensed under a Creative Commons Attribution-NonCommercial 4.0 International License 


\section{A House Burning at Redwine (41SM193)}

\section{Mark Walters}

I explore an unusual Caddo vessel (Figure 1) from the Redwine site (41SM193), a Middle Caddo period (ca. A.D. 1200-1400) habitation/mound site located in Smith County, Texas (Walters and Haskins 1998). This vessel has been described as part of the Walters Collection by Perttula et al. (2009:31-32):

SITE NAME OR SITE NUMBER: 41SM193, Burial 2

VESSEL NO.: 24

NON-PLASTICS: grog

VESSEL FORM: carinated bowl

RIM AND LIP FORM: direct rim and a rounded lip

CORE COLOR: $\mathrm{F}$ (fired in a reducing environment and cooled in the open air)

INTERIOR SURFACE COLOR: strong brown $(7.5 \mathrm{YR} 5 / 6)$

EXTERIOR SURFACE COLOR: strong brown $(7.5 \mathrm{YR} 5 / 6)$

WALL THICKNESS (RIM, BODY, AND BASE IN MM: 7.9 mm, rim

INTERIOR SURFACE TREATMENT: smoothed

EXTERIOR SURFACE TREATMENT: burnished

HEIGHT (IN CM): 8.6

ORIFICE DIAMETER (IN CM): 26.5

DIAMETER AT BOTTOM OF RIM OR NECK (IN CM): 24.0

BASE DIAMETER (IN CM): 10.5

ESTIMATED VOLUME (IN LITERS): 1.37 liters

DECORATION: The rim panel has an idiosyncratic engraved motif that consists of a series of excised and cross-hatched elements that are pendant from the carination that resemble the outlines of Caddo wood "beehiveshaped structures." Interspersed amongst these excised and cross-hatched elements are five engraved semicircles with smaller excised elements pendant from the outer semi-circular line (Perttula et al. 2009:Figure 26). The inner part of the semi-circles have oval-shaped excised zones.

TYPE: Undetermined fine ware 


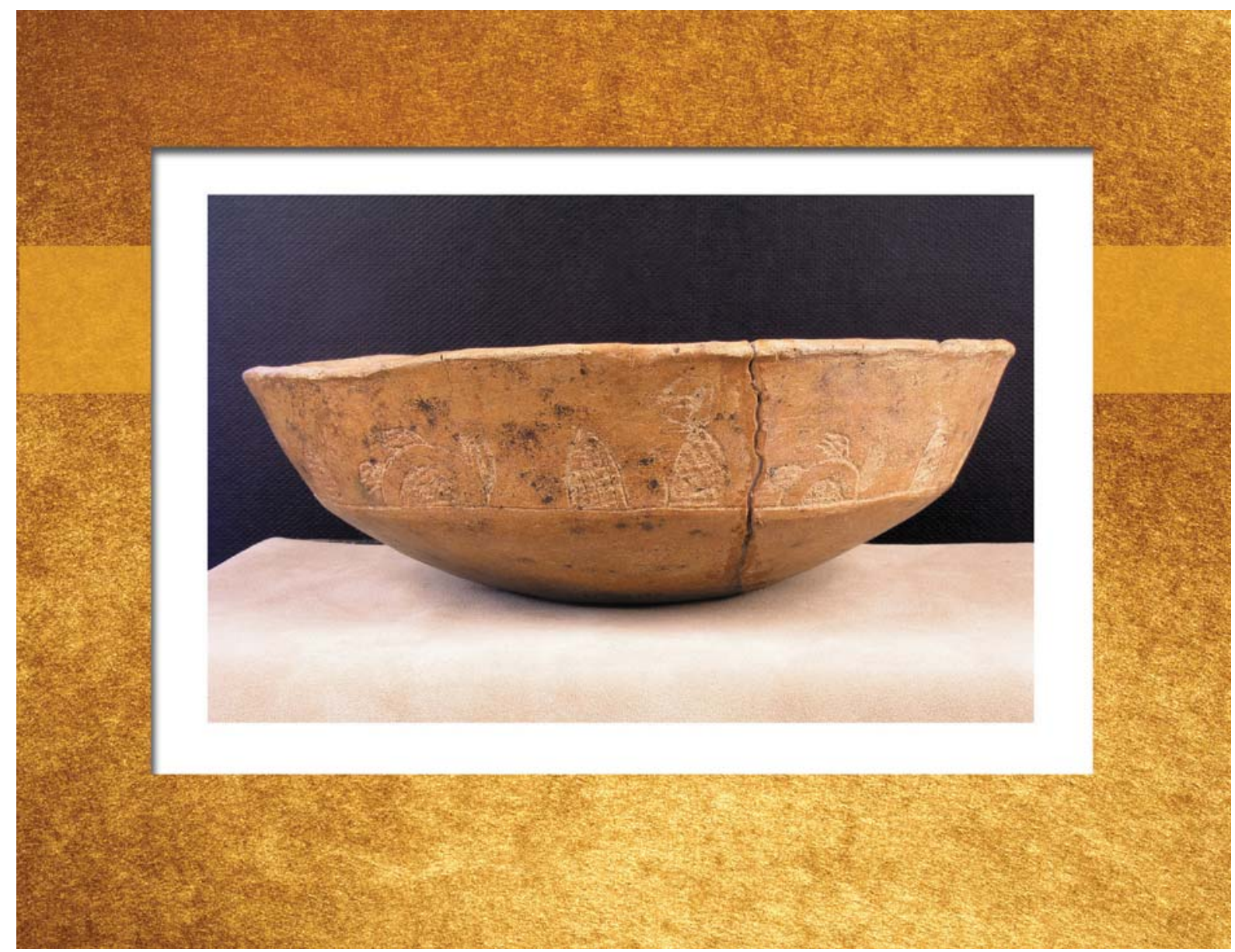

Figure 1. Engraved carinated bowl from the Redwine site.

The engraved motif consists of a horizontal line circling the vessel at the point of carination on which there are 21 evenly spaced cross-hatched elements (Figures 2 and 3) that vary in size and shape.

"Some of the houses, therefore, were well built and tall, others of medium size, and others still smaller like half an orange" (Hidalgo to Viceroy, in Griffith 1954). The Spanish in 1715 decided to re-establish the missions in East Texas and Fray Hidalgo was placed over a mission on the Neches River to serve the Neches, Nabedache, Nacogdoches, and Nocono tribes (Newcomb 1961:287).

This description of Caddo houses by Hidalgo to the Viceroy seems to describe the elements occurring on the Redwine vessel. Note that there are four elements that have a half circle outlining the cross-hatched elements that may depict houses. The outer half circle may represent an earthen mound that was covering the houses. Radiating from the half circles are engraved triangle-like elements that could be interpreted as symbols of fire (Figures 4 and 5). Could this element on the vessel be illustrating a house burning episode and subsequent covering with a mound of soil?

In Figure 2 the third element from the left appears to represent a house with smoke emanating from the top of the house. A similar illustration was drawn of an 1867 Caddo Indian village in Indian Territory (near Anadarko, Oklahoma) by James Reagle, Jr., an Army surgeon at Fort Arbuckle (Figure 6). 


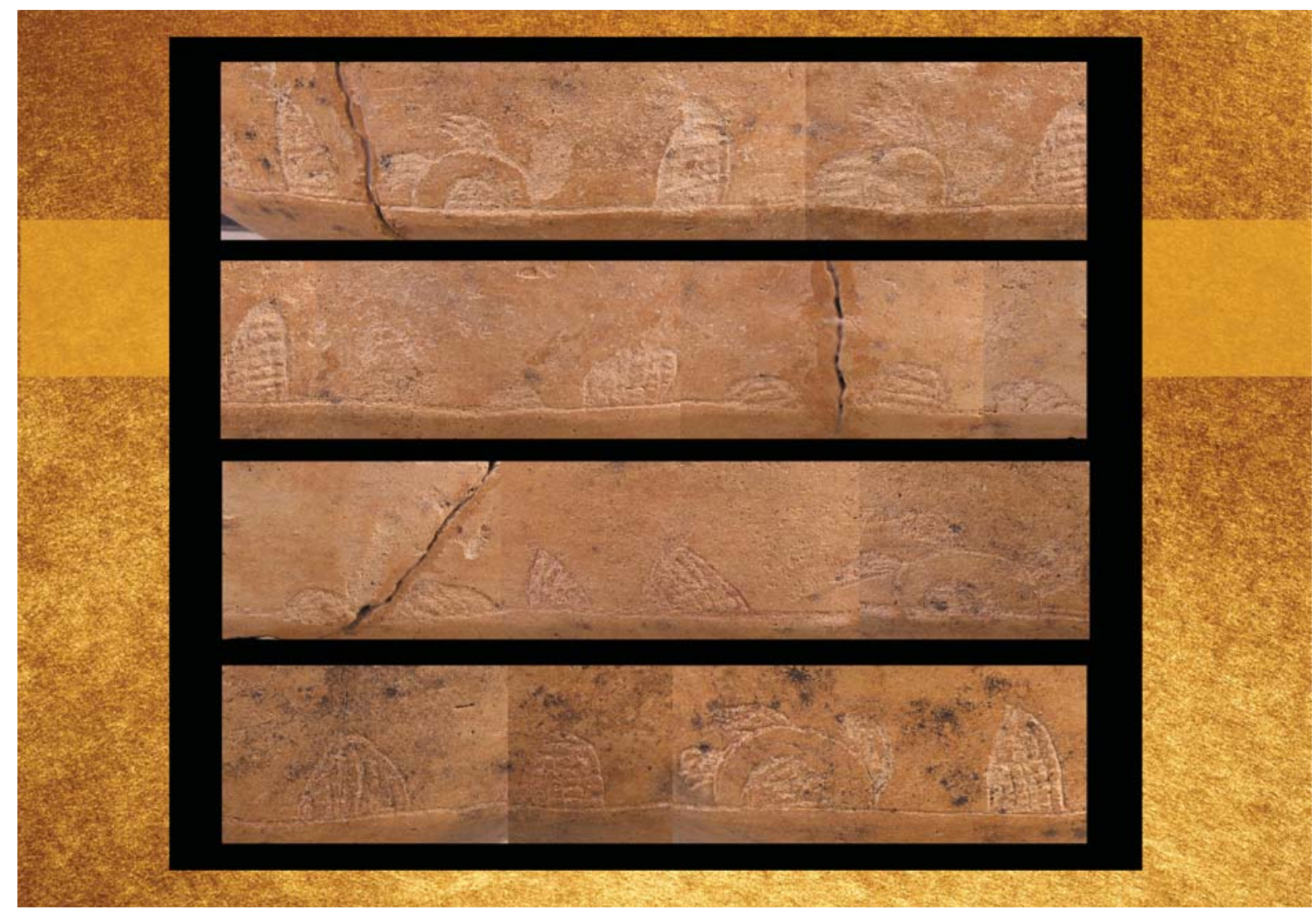

Figure 2. Expanded photo showing entire design on rim.

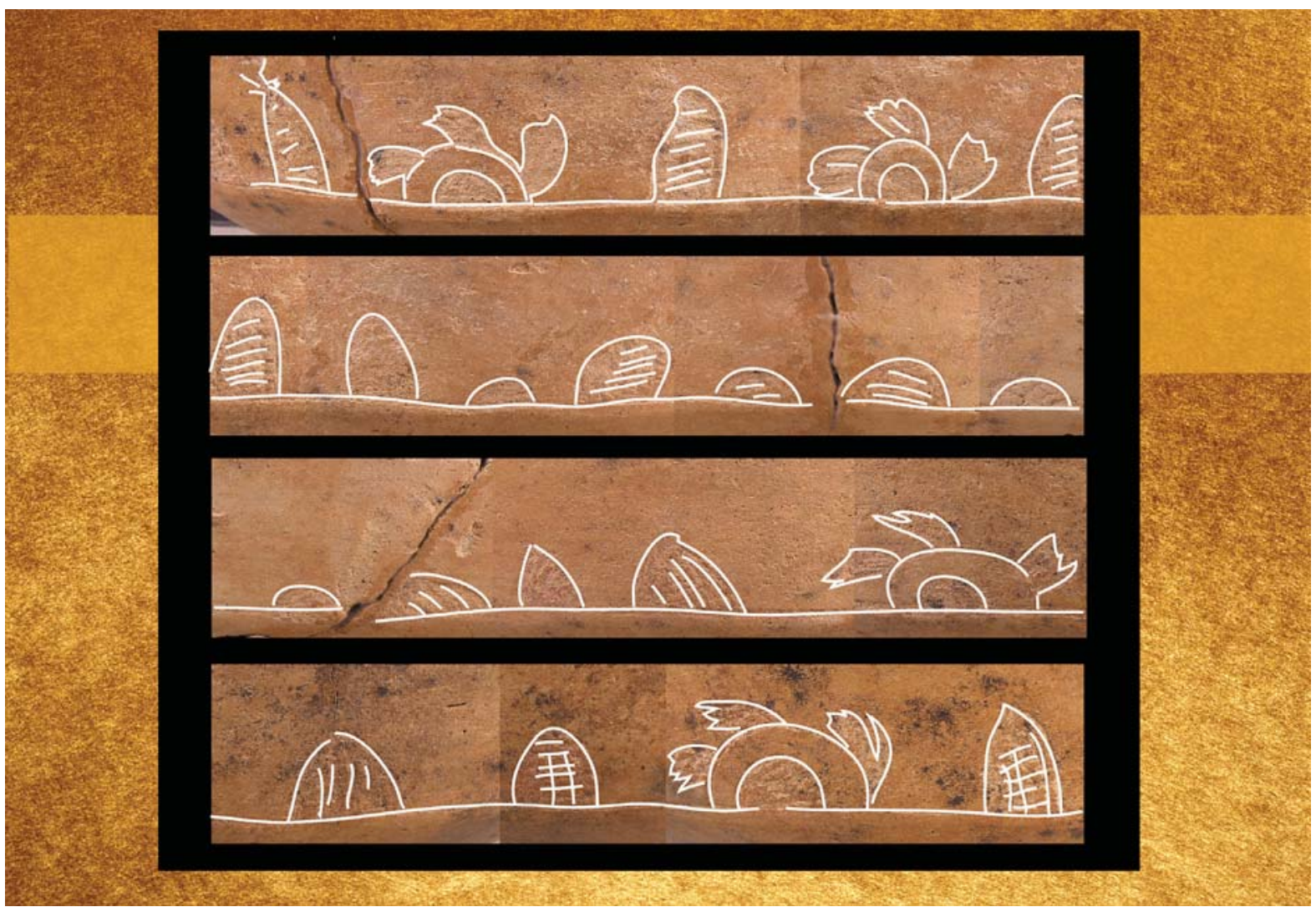

Figure 3. Expanded photo outlined to better depict elements. 


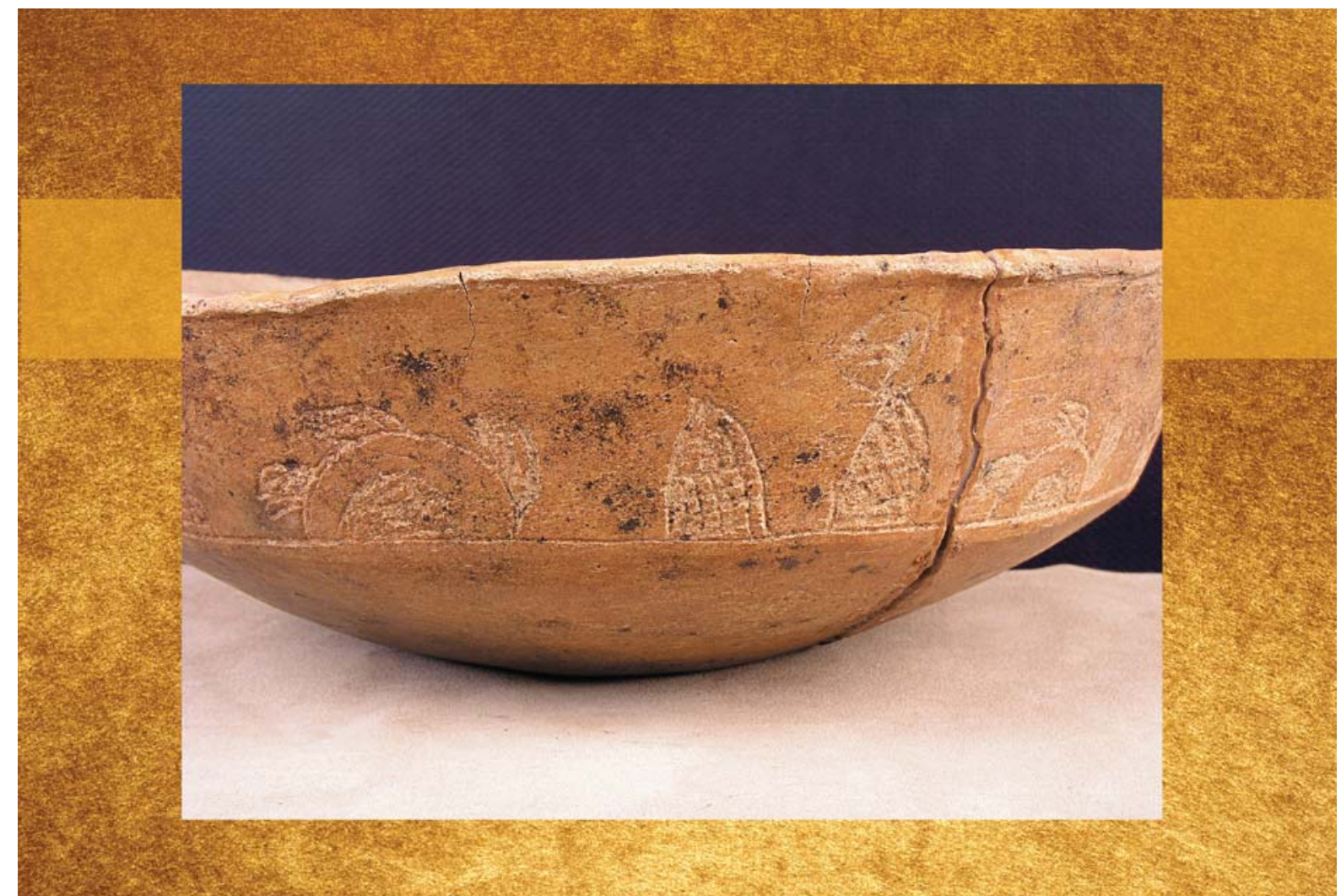

Figure 4. Close-up view showing possible burning/smoke.

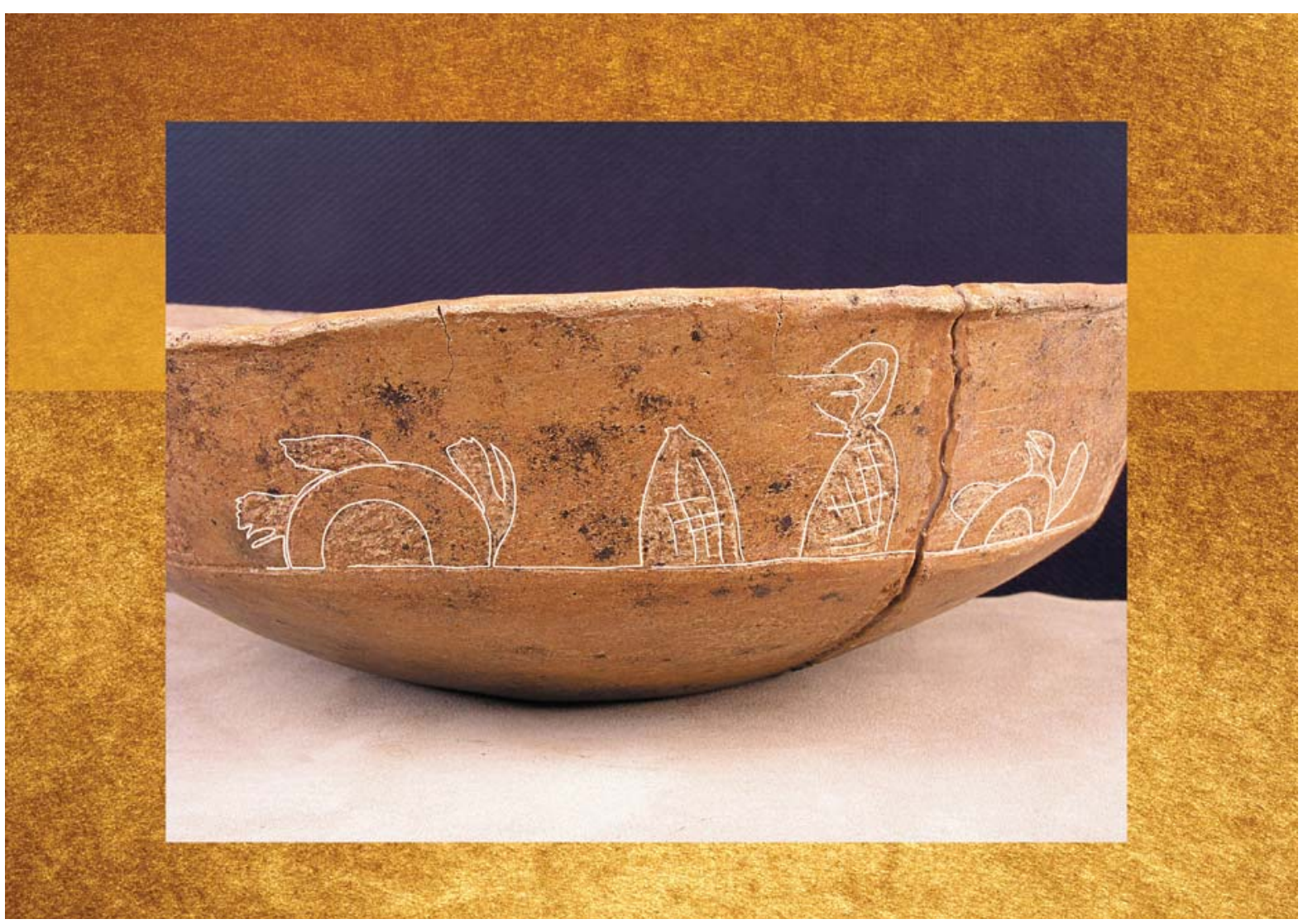

Figure 5. Close-up view outlined to better depict elements. 


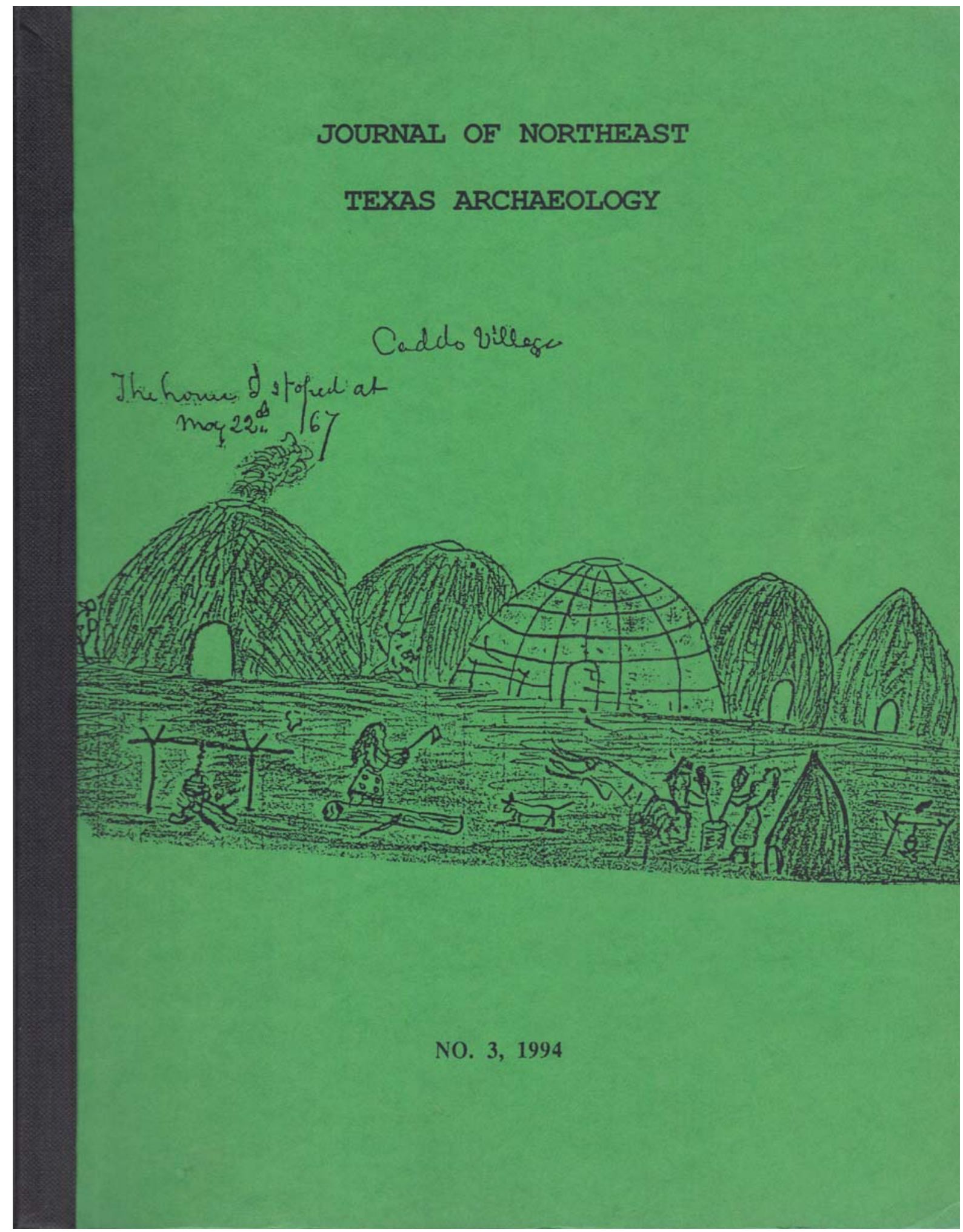

Figure 6. 1867 illustration of a Caddo village in Indian Territory. From James Reagle, Jr. Papers (1864-1867), Western History Collections, The University of Oklahoma. 
These suggestions are conjecture on my part. Nevertheless, it may well be the case that this unique ceramic vessel from the Redwine site is a decorated example of what the houses would have looked like in Caddo villages as described by Hidalgo and Reagle, Jr.

\section{Acknowledgements}

A special thanks to Bryan Boyd, fellow Texas Archeological Steward, Gregg County, Texas, for his help with the photographs.

\section{References Cited}

Griffith, W. J.

1954 The Hasinai Indians of East Texas as Seen by Europeans, 1687-1772. Philological and Documentary Studies, Vol. 2, No. 3. Middle American Research Institute, Tulane University, New Orleans.

Newcomb, W. W., Jr.

1961 The Indians of Texas from Prehistoric to Modern Times. University of Texas Press, Austin.

Perttula, T. K., M. Walters, S. Marceaux, and B. Nelson

2009 Caddo Pottery Vessels and Pipes from Sites in the Middle and Upper Sabine and Upper Neches River Basins, Smith and Wood Counties, Texas. Special Publication No. 7. Friends of Northeast Texas Archeology, Pittsburg and Austin.

Walters, M. and P. Haskins

1998 Archeological Investigations at the Redwine Site (41SM193), Smith County, Texas. Journal of Northeast Texas Archaeology 11:1-38. 